\title{
A New Transoceanic Invasion? First Records of Neomysis americana (Crustacea: Mysidae) in the East Atlantic
}

\author{
Karl J. Wittmann ${ }^{1, *}$, Thomas J. Vanagt ${ }^{2}$, Marco A. Faasse ${ }^{3,4}$ and Jan Mees ${ }^{2}$ \\ ${ }^{1}$ Abteilung für Ökotoxikologie, Zentrum für Public Health, Medizinische Universität Wien, Kinderspitalgasse 15, A-1090 \\ Vienna, Austria \\ ${ }^{2}$ eCOAST Marine Research, Esplanadestraat 1, B-8400 Oostende, Belgium \\ 3 eCOAST Marine Research, P.O.Box 149, 4330 AC Middelburg, The Netherlands \\ ${ }^{4}$ Naturalis Biodiversity Centre, Department of Marine Zoology, P.O. Box 9517, 2300 RA, Leiden, The Netherlands
}

\begin{abstract}
First records in the East Atlantic are reported for the North-West Atlantic endemic mysid Neomysis americana (S. I. Smith, 1873), previously known as an invader of South-West Atlantic coasts. Two specimens were caught in 2010 in coastal waters of The Netherlands. The new records provide the first evidence for a west to east transfer of a mysid species across the Atlantic, whereas previously published transfers were observed only in the opposite direction. Major diagnostic characters are reconsidered and the validity of the European species of Neomysis and Acanthomysis is discussed. A pictorial key to these species is given to facilitate future assessments of potential range expansions of $N$. americana.
\end{abstract}

Keywords: Acanthomysis, East Atlantic neozoans, Key to species, Neomysis, The Netherlands, Transoceanic expansion, West Atlantic endemics.

\section{INTRODUCTION}

There is currently great concern about the rapid invasion of the Ponto-Caspian mysid Hemimysis anomala G.O. Sars into the aquatic biota of North America, due to possible detrimental effects as a predator of zooplankton, especially of daphniids [1]. This species lives in fresh- to brackish waters and may have crossed the Atlantic in ballast water of transoceanic ships. A likely scenario involves the busy transoceanic harbors on the coast of the Netherlands, where it was first recorded in 1997 [2]. Less commonly known is the case of the marine euryhaline, North-East Atlantic endemic Praunus flexuosus (O.F. Müller): it first appeared in about 1960 on the east coast of North America [3], possibly also mediated by ballast water [4]. The present contribution provides the first indication of a successful transfer of a mysid species in the opposite direction. Nonetheless, evidence of a potential long-term establishment in European waters is still lacking. A profound knowledge of the local endemics is essential for reliable classification of any newly recorded species as non-indigenous. Therefore, the major diagnostic characters and the taxonomic validity of the European relatives are reconsidered with respect to the new immigrant. A pictorial key to these species is given to facilitate future assessments of potential adventive species and their range expansions.

*Address correspondence to this author at the Abteilung für Ökotoxikologie, Zentrum für Public Health, Medizinische Universität Wien, Kinderspitalgasse 15, A-1090 Vienna, Austria; Tel: +43 66480016 34910; Fax +431 40160 934927; E-mail: karl.wittmann@meduniwien.ac.at

\section{MATERIAL AND METHODS}

As part of the ecological monitoring of a beachnourishment project on the Wadden Sea island of Ameland on the north coast of The Netherlands, benthic samples were taken on the North Sea coasts of two islands, Ameland and to the east Schiermonnikoog. The sea side of Schiermonnikoog is characterized by an exposed, barred dissipative beach [5] with two subtidal bar-troughs. The sediment is fine, wellsorted sand with a median grain size between 230 and 240 $\mu \mathrm{m}$. The beach is considered pristine, i.e. with no nourishment (sand supply from elsewhere) history. Samples were taken with van Veen grabs - normally not well suited to capture hyperbenthic organisms such as mysids.

Salinity (S) is expressed as a dimensionless equivalent of electric conductivity. Body length was measured from the tip of the rostrum to the terminal margin of the telson without spines. Dissected parts were mounted in a bleaching medium (Swan medium [6]) on slides. Examined materials belong to the introduced species Neomysis americana (Dutch specimens and comparable specimens from various locations in North America) and the native species Neomysis integer and Acanthomysis longicornis, with which it is most likely to be confounded in Europe. The materials were deposited at the NCB Naturalis (Netherlands Centre for Biodiversity; reg. nos. RNMH.CRUS.E.3779 to RNMH.CRUS.E.3783) and the Natural History Museum of Vienna (22995, 25447-25450):

Neomysis americana (S.I. Smith, 1873) [7]: 1 female incubating 11 postnauplioid larvae, North Sea, north coast of The Netherlands, Schiermonnikoog, N53 30.575, E06 
16.184, marine, van Veen grab, 0.7 m, 24 Sept. 2010, 01:46 h. -1 immature male, coast at Schiermonnikoog as above, N53 30.642, E06 17.292, marine, van Veen grab, 1.0 m, 24 Sept. 2010, 02:11h. - 10 spec., east coast of North America, North Carolina, Oregon Inlet, night plankton tows, 9-10 Jan. 1957, leg. A.B. Williams, det. T.E. Bowman. - 24 spec., from Gulf of Mexico, culture stock of Environmental Research Laboratory, Narragansett, Rhode Island, USA, 1985, leg. et det. Suzanne M. Lussier.

Neomysis integer (Leach, 1814) [8]: 98 spec., southern Baltic, Fehmarn-Belt, Puttgarden, N54 30.30, E11 13.32, sandy shore, $\mathrm{S}=14,0.3 \mathrm{~m}$, hand net, 23 Aug. 1985, leg. Ariani \& Wittmann. - 3 spec., west coast of Scotland, Argyll, Firth of Lorn, Dunstaffnage Bay, N56 27.00, W05 25.98, S = 28-33, 0.1-0.2 m, algae, mud, hand net, 13 Sept. 1983, leg. K.J. Wittmann. - 68 spec., coast of the North Sea, Den Helder, Noordhollands kanaal, N52 57.828, E04 46.002, $\mathrm{S}=2-3,1-2 \mathrm{~m}$, macrophytes, hand net, 22 June 1989, leg. K.J. Wittmann. - 114 spec., Gulf of Biscay, Bassin d'Arcachon, chenal de La Hume, N44 35.526 W01 7.422, S $=1.2$, 2 Aug. 1983, leg. et det. J.C. Sorbe. -2 adults, Mediterranean coast of France, delta of the Rhône River, Canal d'Arles à Fos at its crossing with the Liaison RhôneFos, N43 27.9867, E04 50.0042, $\mathrm{S}=12.3,0.5-1.5 \mathrm{~m}$, concretions of Mytilus, mud, hand net, 14 June 2007, leg. K.J. Wittmann.

Acanthomysis longicornis (H. Milne Edwards, 1837) [9]: 8 spec., Mediterranean, Adriatic Sea, Gulf of Trieste, Bay of Strunjan, N45 33.00, E13 34.98, S = 31-33, 22 m, mud with Cucumaria, diver-operated hand net, 14 Feb. 1975, leg. K.J. Wittmann. - 11 spec., Mediterranean, Tyrrhenian Sea, Gulf of Salerno, Lido Lago, N40 33.00, E14 52.98, S = 37, 7-10 $\mathrm{m}, 1700 \mathrm{~m}$ off sandy beach, sand, Cymodocea, boat-operated bottom net, 16 July 1995, leg. K.J. Wittmann.

\section{RESULTS}

Two specimens of Neomysis americana were unexpectedly sampled with van Veen grabs in very shallow marine coastal waters of The Netherlands along the North Sea coast of Schiermonnikoog (see material listed above). The collected specimens of $N$. americana were accompanied by numerous specimens of the amphipods Bathyporeia pelagica (Bate) and B. elegans Watkin, one specimen of the amphipod Pontocrates altamarinus (Bate \& Westwood), one specimen of the mysid Schistomysis kervillei (G.O. Sars), two specimens of the isopod Eurydice pulchra Leach, and one specimen of the decapod shrimp Crangon crangon (Linnaeus) [10].

Morphology of $N$. americana from The Netherlands (Fig. 1b,e,h): The adult female with body length $9.6 \mathrm{~mm}$, and if extrapolating from the immature male $(5.0 \mathrm{~mm})$ to a mature individual, showed intermediate body size between the large winter animals from North Carolina $(1 \mathrm{~F}$ ad. $10.7 \mathrm{~mm}, 3 \mathrm{~F}$ subad. 9.1-11.6 mm, $6 \mathrm{M}$ subad. 7.3-10.2 mm) and the small specimens from the Gulf of Mexico in laboratory culture (12 $\mathrm{F}$ ad. 7.0-8.3 mm, $3 \mathrm{~F}$ subad. 6.3-6.5 mm, $9 \mathrm{M}$ ad. 5.7-7.8 $\mathrm{mm}$ ), these latter likely corresponding to summer animals. Among the main diagnostic characters examined in the adult female (data for the immature male in parentheses), the terminal segment was $16-17 \%(15-17 \%)$ of the entire length of the lanceolate antennal scale; this scale was 2.5-2.8 (2.3-
2.4) times the length of the trunk of the antennal flagellum. Endopods of uropods with comb-like series of 16-17 (13) spines on ventral face near statocyst, these spines continuously increasing in length caudally. Triangular telson with 29-34 (21-23) spines distributed over entire length of each lateral margin; spines on terminal half of telson arranged in groups of large spines with 1-5 (1-3) small spines in between. As for body size, the data for antennal scale, uropods, and telson are between and/or close to the average values found in North Carolina and the Gulf of Mexico materials.

Morphology of the three species studied (adults of both sexes; Fig. 1): antennal scale length divided by length of the trunk of the antennal flagellum was 2.8-3.2 in $N$. integer, 2.3-2.8 in N. americana, and 1.3-1.5 in Acanthomysis longicornis. Endopods of uropods with 18-40 spines below statocyst in N. integer, 8-25 in N. americana, and 2-3 in A. longicornis. Only in $N$. integer were these spines inserted (always) on a longitudinal ridge below the statocyst. Only $A$. longicornis with scales scattered over large parts of the body surface and certain appendages, giving the body a hispid appearance. Both Neomysis species with triangular telson, armed with series of spines along entire lateral margins, unlike the more linguiform telson with a spine-free zone along most of the basal third in A. longicornis. Number of spines on each lateral margin of the telson was 16-24 in $N$. integer, 20-43 in N. americana, and 31-40 in A. longicornis, not counting the large apical spines. Terminal half of the telson of $N$. americana and A. longicornis with groups of large spines with small spines in between, unlike the almost continuous series of spines along the lateral margins in $N$. integer. Dense series of thin hairs were detected on the inner margins of both rami of the uropods and on both lateral margins of the telson in dissected parts of $N$. integer. These hairs were up to half the length of the lateral spines of the telson, but were so thin that 200-400x magnification was needed for definite identification (not visible with the low magnification in Fig. 1g,h). Some hairs were also present in $N$. americana, but were not easy to see in the small space between the spines on the lateral margins of the telson. No such hairs were seen in the dissected uropods and telson of A. longicornis.

\section{DISCUSSION}

Neomysis americana is well known as the most common mysid in brackish waters and as a less common faunal element in marine waters down to $240 \mathrm{~m}$ depth along western Atlantic coasts between southern Newfoundland and Florida [11]. In the 1970-80s it surprisingly appeared along the coasts of Uruguay and Argentina [12], where it may have been transferred in ballast water [13]. Accordingly, the new records in The Netherlands appear to be a continuation of long-term anthropogenic expansion processes across oceanic basins. Both new records are based on an inefficient method for sampling mysids, suggesting that many more individuals were present but escaped.

We found no consistent morphological differences between and within field materials from The Netherlands and North Carolina, and culture animals from the Gulf of Mexico. According to Wigley [3] and Hoffmeyer [12], there are no differences, other than those related to sex and body 


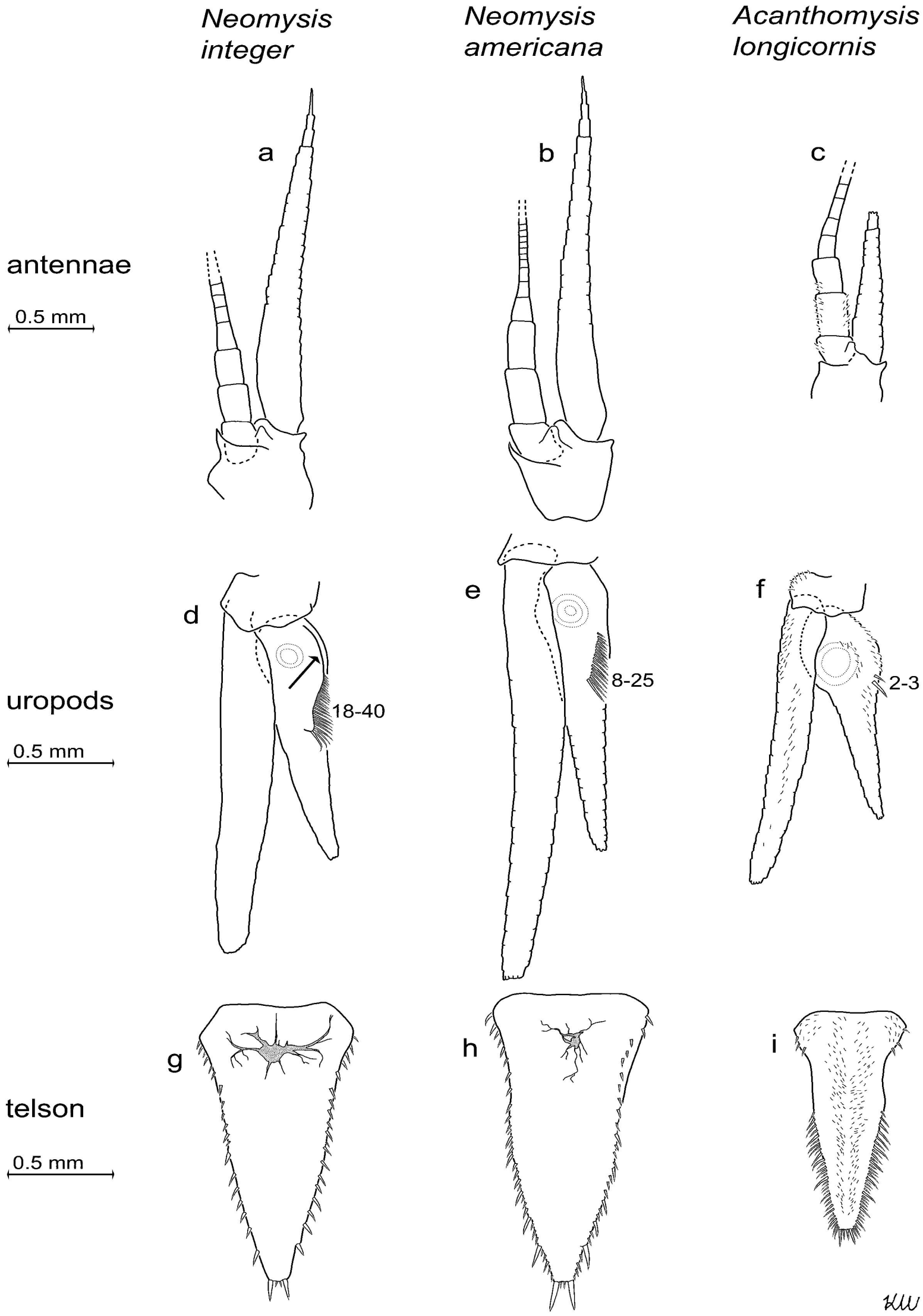

Fig. (1). Pictorial key to Neomysis integer, N. americana, and Acanthomysis longicornis encountered in coastal waters of western Europe. The three species are clearly distinguished by the length relation between the antennal scale and the trunk of the antennal flagellum, by the numbers of spines on the ventral face of the endopods of uropods, by the presence of a longitudinal ridge (d, arrow) below the statocyst, and by the size and arrangement of spines on the lateral margins of the telson. (a-f), setae omitted. 
size, between and within populations on the coasts of Canada, the United States, Uruguay, and Argentina. Therefore, morphological characters do not appear suitable to identify the source area of the European animals, which is expected to be anywhere along the coast of the West Atlantic between $50^{\circ} \mathrm{N}$ and $40^{\circ} \mathrm{S}$, except tropical latitudes.

$N$. americana (Fig. 1b,e,h) shows great morphological similarity with the native European species $N$. integer (Fig. $\mathbf{1 a , d , g ) . ~ T h e ~ l a t t e r ~ i s ~ a ~ c o m m o n ~ c o n s t i t u e n t ~ o f ~ b r a c k i s h ~ w a t e r ~}$ faunas and is less common in marine waters down to $30 \mathrm{~m}$ depth. It occurs in the south-western Barents Sea and along north-eastern Atlantic coasts southward down to southern Spain [14], in the Baltic, and as a potential neozoan locally also in the western Mediterranean [15]. True freshwater populations of $N$. integer do exist but are rare [16]. This species appears to be somewhat more euryhaline and less thalassophilic than $N$. americana.

We acknowledge only one additional, closely related species, endemic to the North-East Atlantic, namely Acanthomysis longicornis (Fig. 1c,f,i). There are only 2-3 spines below the statocyst, as already emphasized by Ariani [17] and Holmquist [18]. Additional small spines seen in this spine series by Sars [19] and Tattersall \& Tattersall [20] actually belong to the scales widely scattered over the body and appendages ("general spininess" according to Holmquist [18]). This species lives over soft bottoms in 2-100 m depths along the coasts of the North-East Atlantic from the North Sea to the Gulf of Biscay, and more commonly of the Mediterranean Sea. In summary, there is only one native species each of Neomysis and Acanthomysis in North-East Atlantic waters. In contrast, there are many species of both genera in the Pacific and Indian Oceans [21]. The Pacific species most similar to $N$. americana is $N$. orientalis Ii, 1964 [22]. The latter clearly differs by more (about 27) spines in more marginal position ventrally on the endopods of uropods [22].

We do not acknowledge Acanthomysis strauchi (Czerniavsky, 1882) [23], to date very often cited for European waters in the secondary literature [f.i. 21,24,25] including online databases [f.i. 26-28]. We consider it to actually be a junior synonym of the Ponto-Caspian endemic Paramysis ullskyi Czerniavsky, 1882. Our exhaustive literature survey showed that this invalid taxon was created in 1957 as a twofold bibliographic error by Gordan [29], who firstly overlooked that Metamysis strauchi (Czerniavsky, 1882) was already synonymized with $P$. ullskyi in 1939 by Derzhavin [30]. Secondly, she confounded the genus name Metamysis G.O. Sars, 1895 [31], now considered a subgenus [32] of Paramysis Czerniavsky, 1882, with the homonym Metamysis Nakazawa, 1910 [33], in turn in 1957 still considered a junior synonym of Acanthomysis Czerniavsky, 1882, but now an invalid senior synonym of Orientomysis Derzhavin, 1913 [34]. More recently, $A$. strauchi was quoted in the secondary literature [24,25] for the Mediterranean, without indication of primary literature or data sources for this binomen. Consequently, neither $P$. ullskyi nor any Acanthomysis species other than $A$. longicornis are acknowledged by us for the Mediterranean.

At present it appears uncertain whether $N$. americana will become a permanent constituent of the European fauna. All keys to species currently utilized in Europe indicate $N$. integer as the only local representative of its genus. One cannot exclude that $N$. americana has already gained a wider distribution along European coasts but has been overlooked. Future sampling programs should take the potential presence of this species into account and may, to this end, use the pictorial key in Fig. (1) as a supplement to already established keys [f.i. 35-37].

\section{CONFLICT OF INTEREST}

The authors confirm that this article content has no conflicts of interest.

\section{ACKNOWLEDGEMENTS}

The present work is part of an ongoing coastal nourishment research project, funded by the Dutch Ministry of Infrastructure and Environment. The authors thank Harriette Holzhauer and Jan van Dalfsen (Deltares) for their scientific support, and Jannes Heusinkveld (The Fieldwork Company) for leading the field campaign. Bert Hoeksema (NCB Naturalis) commented on an early draft of the manuscript.

\section{REFERENCES}

[1] Ricciardi A, Avlijas S, Marty J. Forecasting the ecological impacts of the Hemimysis anomala invasion in North America: lessons from other freshwater mysid introductions. J Great Lakes Res 2011; 38(Suppl 2): 7-13.

[2] Faasse MA. The pontocaspian mysid, Hemimysis anomala Sars, 1907, new to the fauna of the Netherlands. Bull Zoöl Mus Univ Amsterdam 1998; 16: 73-6.

[3] Wigley RL. Occurrence of Praunus flexuosus (O.F. Müller) (Mysidacea) in New England waters. Crustaceana 1963; 6: 158.

[4] Carlton JT. Transoceanic and interoceanic dispersal of coastal marine organisms: the biology of ballast water. Oceanogr Mar Biol Ann Rev 1985; 23: 313-71.

[5] Short A. The role of wave height, period, slope, tide range and embaymentisation in beach classifications: a review. Rev Chil Hist Nat 1996; 69: 589-604.

[6] Dunger W. Tiere im Boden. Wittenberg-Lutherstadt: Ziemsen 1964.

[7] Smith SI. Report upon the invertebrate animals of Vineyard Sound and the adjacent waters, with an account of the physical characters of the region. Rep US Comm Fish Fisheries 1873; 1871-2 (Pt 1, No. 18): 295-747.

[8] Leach WE. Crustaceology. Brewster's Edinburgh encyclopaedia 1814; $7: 383-437$.

[9] Milne-Edwards H. Histoire naturelle des Crustacés, comprenant l'anatomie, la physiologie et la classification de ces animaux. In: Collection des suites a Buffon formant avec les œuvres de cet auteur un cours complet d'histoire naturelle, vol. 2. Paris: Libraire Encyclopédique de Roret, 1837.

[10] Vanagt T, Van de Moortel L, Heusinkveld J, et al. Veldcampagne ecologie Ameland 2010. eCOAST rapport 2010014-4; 2011.

[11] Williams AB, Bowman TE, Damkaer DM. Distribution, variation and supplemental description of the opossum shrimp, Neomysis americana (Crustacea: Mysidacea). Fish Bull 1974; 72: 835-42.

[12] Hoffmeyer MS. The occurrence of Neomysis americana in two new localities of the South American coast (Mysidacea). Crustaceana 1990; 58: 186-92.

[13] Carlton JT, Geller JB. Ecological roulette: The global transport of nonindigenous marine organisms. Science 1993; 261: 78-82.

[14] Cuesta JA, Serrano L, Bravo MR, Toja J. Four new crustaceans in the Guadalquivir River Estuary (SW Spain), including an introduced species. Limnética 1996; 12: 41-5.

[15] Wittmann KJ, Ariani AP. Reappraisal and range extension of nonindigenous Mysidae (Crustacea, Mysida) in continental and coastal waters of eastern France. Biol Invasions 2009; 11: 401-7. 
[16] Braune M. Biologie flussnaher Abgrabungsgewässer. Einsatzmöglichkeiten und Potentiale als Ersatzbiotope in Auengebieten Diss Univ Hannover 2004

[17] Ariani AP. Osservazioni su misidacei della costa adriatica pugliese. Ann Ist Mus Zool Univ Napoli 1967; 18: 1-38, 3 pls.

[18] Holmquist C. The genus Acanthomysis Czerniavsky, 1882 (Crustacea, Mysidacea). Zool Jb Syst 1981; 108: 386-415.

[19] Sars GO. Nye Bidrag til Kundskaben om Middelhavets Invertebratfauna I. Middelhavets Mysider. Arch Math Naturv 1877; 2: 10-119, Pls. 1-36.

[20] Tattersall WM, Tattersall OS. The British Mysidacea. London: Ray Society, Monograph no. 136; 1951.

[21] Anderson G. Mysida Classification [bibliography on the internet]. Instant Web Publishing, USA; p. 1-24 [updated 2010 January 20]; Available from: http://peracarida.usm.edu/MysidaTaxa.pdf [cited 2010 January 21].

[22] Ii N. Fauna Japonica - Mysidae (Crustacea). Tokyo: Biogeographical Society of Japan 1964.

[23] Czerniavsky V. Monographia Mysidarum inprimis Imperii Rossici. Fasc. 1, 2. Trudy St.-Peterburgskago obsch est 1882; 12: 1-170; 13: $1-85$, Pls. I-IV.

[24] Müller H-G. World catalogue and bibliography of the recent Mysidacea. Wetzlar: Wissenschaftlicher Verlag 1993.

[25] San Vicente C. Mysidaceans. In: Coll M, Piroddi C, Steenbeek J, et al., Eds. Biodiversity of the Mediterranean Sea: estimates, patterns $\&$ threats. PLoS One [serial on the internet]. 2010; 5(8): e11842: 254-275. Available from: www.plos-one.org [cited 2011 March 30]

[26] WoRMS (World Register of Marine Species) [database on the internet]. Acanthomysis strauchi (Czerniavsky, 1882). Belgium:
The Flanders Marine Institute (VLIZ); Available from: http://www.marinespecies.org/aphia.php?p=taxdetails\&id=119940 [cited 2012 July 19].

[27] NeMys [database on the internet]. Acanthomysis strauchi (Czerniavsky, 1882). Available from: http://nemys.ugent.be/species.asp? spec $=15188 \&$ group $=1$ [cited 2012 July 19].

[28] EOL (Encyclopedia of Live) [database on the internet]. Acanthomysis strauchi(Czerniavsky, 1882). Available from: http://eol.org/pages/1022029/overview [accessed 2012 July 19].

[29] Gordan J. A bibliography of the order Mysidacea. Bull Am Mus Nat Hist 1957; 112: 281-393.

[30] Derzhavin AN. Mizidy Kaspiya. Baku: Akademiya Nauk SSSR Azerbajdzhanskij Filial Zoologicheskij Institut 1939.

[31] Sars GO. Crustacea Caspia. Account of the Mysidae in the collection of Dr. O. Grimm. Bull Acad Imp Sci St.-Pétersbourg 1895; Ser. 5, 3 (5): 433-58, Pls. I-VIII.

[32] Daneliya ME. K sistematike mizid roda Paramysis (Crustacea, Mysidacea) iz basseina Ponto-Kaspiya. Zool Zh 2004; 83: 408-16.

[33] Nakazawa K. Notes on Japanese Schizopoda. Annot Zool Japonensis 1910; 7: 247-61, pl. VIII.

[34] Derzhavin AN. Neue Mysiden von der Küste der Halbinsel Kamtschatka. Zool Anz 1913; 43: 197-204.

[35] Borghouts-Biersteker CH. Aasgarnalen (Mysidacea). Tabellenserie Strandwerkgemeenschap no.25. KNNV, NJN \& ACJN; 1983

[36] Hayward PJ, Ryland JS, Eds. Handbook of the Marine Fauna of North-West Europe. Oxford, UK: Oxford University Press 1995.

[37] Newell GE, Newell RC. Marine plankton. A practical guide. Pennington, GB: Pisces Conservation Ltd. 2006.

(C) Wittmann et al.; Licensee Bentham Open.

This is an open access article licensed under the terms of the Creative Commons Attribution Non-Commercial License (http://creativecommons.org/licenses/by$\mathrm{nc} / 3.0 /$ ), which permits unrestricted, non-commercial use, distribution and reproduction in any medium, provided the work is properly cited. 